\title{
Mode of Oxygen and Carbon Dioxide Action on Strawberry Ester Biosynthesis
}

\author{
Dangyang Ke, Lili Zhou, and Adel A. Kader ${ }^{1}$ \\ Department of Pomology, University of California, Davis, CA 95616
}

Additional index words. Fragaria ananassa, fermentation volatiles, pyruvate decarboxylase, alcohol dehydrogenase, alcohol acetyltransferase, $\mathrm{pH}$, flavor

\begin{abstract}
Chandler' strawberries (Fragaria ananassa Duck.) were kept in air, $0.25 \% \mathrm{O}_{2}, 21 \% \mathrm{O}_{2}+50 \% \mathrm{CO}_{2}$, or $0.25 \mathrm{O}_{2}$ $+50 \% \mathrm{CO}_{2}$ (balance $\mathrm{N}_{2}$ ) at $5 \mathrm{C}$ for 1 to 7 days to study the effects of controlled atmospheres (CAs) on volatiles and fermentation enzymes. Concentrations of acetaldehyde, ethanol, ethyl acetate, and ethyl butyrate were greatly increased, while concentrations of isopropyl acetate, propyl acetate, and butyl acetate were reduced by the three CA treatments compared to those of air-control fruit. The CA treatments enhanced activities of pyruvate decarboxylase (PDC) and alcohol dehydrogenase (ADH) but slightly decreased activity of alcohol acetyltransferase (AAT). The results indicate that the enhanced PDC and ADH activities by CA treatments cause ethanol accumulation, which in turn drives the biosynthesis of ethyl esters. The increased ethanol concentration also competes with other alcohols for carboxyl groups for esterification reactions. The reduced AAT activity and limited availability of carboxyl groups due to ethanol competition decrease production of other acetate esters.
\end{abstract}

Controlled atmospheres (CAs) can be used to delay senescence and control decay and insects of strawberries (Aharoni et al., 1979; Couey and Wells, 1970; Couey et al., 1966; El-Kazzaz et al., 1983; Harris and Harvey, 1973; Ke et al., 1991; Li and Kader, 1989; Prasad and Stadelbacher, 1974; Smith, 1957; Woodward and Topping, 1972). Exposure to CAs reduced respiration and ethylene production rates and retarded softening of strawberries (ElKazzaz et al., 1983; Ke et al., 1991; Li and Kader, 1989; Woodward and Topping, 1972). Keeping strawberries in $<1 \% \mathrm{O}_{2}$ and/or $>20 \%$ $\mathrm{CO}_{2}$ caused accumulations of certain volatile compounds (Ke et al., 1991; Li and Kader, 1989; Prasad and Stadelbacher, 1974; Smith, 1957; Ueda and Bai, 1993; Woodward and Topping, 1972).

Volatiles are important contributors to flavor and odor of fruit and vegetables. Pyruvate decarboxylase (PDC) and alcohol acetyltransferase (ADH) are two important enzymes responsible for acetaldehyde and ethanol production, and their activities were increased by some CA treatments (Ke et al., 1993). Esters are the volatiles formed by esterification of alcohols and carboxyl groups. Ethyl acetate is produced through an esterification reaction catalyzed by the enzyme alcohol acetyltransferase (AAT), using ethanol and acetyl CoA as substrates (Harada et al., 1985). Fellman et al. (1993a, 1993b) reported that AAT activity increased with advanced maturity of apples but was suppressed by exposure to $0.5 \%$ or $1 \% \mathrm{O}_{2}$. Mattheis et al. (1991) found that storing apples in $0.05 \% \mathrm{O}_{2}$ caused accumulations of several ethyl esters, a condition that was associated with a decrease in concentrations of other esters requiring the same carboxylic acid group for synthesis. Hansen et al. (1992) showed that keeping apples in $1 \%$ to $4 \% \mathrm{O}_{2}$ decreased propyl acetate and butyl acetate. Treating oranges with $<1 \% \mathrm{O}_{2}$ for $24 \mathrm{~h}$ increased concentrations of ethyl acetate, ethyl butyrate, methanol, and ethanol (Shaw et al., 1990). Ke et al. (1991) found that strawberries kept in $<0.25 \% \mathrm{O}_{2}$ or $>50 \% \mathrm{CO}_{2}$ for $>6$ days developed off-flavor, which was correlated with the accumulation of acetaldehyde, ethanol, and ethyl acetate. Ueda and Bai (1993) found that evolution of ethyl acetate and ethyl

Received for publication 4 Oct. 1993. Accepted for publication 7 Feb. 1994. Research supported in part by U.S. Dept. of Agriculture grant no. 58-319R-3-004. The cost of publishing this paper was defrayed in part by the payment of page charges. Under postal regulations, this paper therefore must be hereby marked advertisement solely to indicate this fact.

${ }^{1}$ To whom reprint requests should be addressed. butyrate was increased by exposing strawberries to $20 \% \mathrm{CO}_{2}$ for 2 days at $1 \mathrm{C}$.

Applying ethanol postharvest caused accumulation of ethyl esters and decreased concentrations of butyl esters and hexyl esters in apples (Berger and Drawert, 1984). Exposing feijoa fruit to acetaldehyde vapor enhanced taste and volatile concentrations; however, the same treatment caused off-flavor and too-high concentrations of ethanol, ethyl acetate, and ethyl butyrate in strawberries (Pesis et al., 1989).

In this research, we studied the regulation of ester biosynthesis in strawberries kept in $0.25 \% \mathrm{O}_{2}$ and/or $50 \% \mathrm{CO}_{2}$, with emphasis on the mode of CA action on acetate ester production.

\section{Materials and Methods}

Materials and treatments. 'Chandler' strawberries were obtained on the day of harvest from a commercial shipper in Oxnard, Calif. Damaged and nonuniform fruit were eliminated, and good fruit were matched by color to remove unripe and overripe fruit. Twenty selected fruit were placed in a 4-liter glass jar at 5C and ventilated with humidified air or a specified gas mixture at a continuous $50-\mathrm{ml} \cdot \mathrm{min}^{-1}$ flow rate for up to 7 days. The gas mixtures included $0.25 \% \mathrm{O}_{2}+99.75 \% \mathrm{~N}_{2}, 21 \% \mathrm{O}_{2}+50 \% \mathrm{CO}_{2}+29 \% \mathrm{~N}_{2}$, and $0.25 \% \mathrm{O}_{2}+50 \% \mathrm{CO}_{2}+49.75 \% \mathrm{~N}_{2}$. Daily, half of the fruit was used to extract juice to measure volatiles and the other half was used to extract fermentation enzymes. Three replicates were used for each treatment.

Measuring volatiles. Frozen fruit juice was thawed and a 5-ml sample was put in a 15-ml screw-cap test tube. The tube was closed with an elastic cap and incubated at 60C. After $60 \mathrm{~min}$, a 1-ml headspace gas sample was taken with a 1-ml glass syringe. Concentrations of acetaldehyde, ethanol, ethyl acetate, ethyl butyrate, and other esters were measured by injecting the sample into a gas chromatograph (HP5890A; Hewlett Packard, Palo Alto, Calif.) with a flame ionization detector (at 250C) and a glass column $(2 \mathrm{~mm} \times 1.0 \mathrm{~m})$ containing $5 \%$ Carbowax on a $60 / 80$ Carbopack as the stationary phase (Supelco, Bellafonte, Pa.) at 120C.

Determining fermentation enzymes. To extract PDC and ADH, $3 \mathrm{~g}$ of tissue was sliced from three strawberries and homogenized in $10 \mathrm{ml}$ of $100 \mathrm{~mm} 2-(\mathrm{N}$-morpholino)ethane-sulfonic acid (MES) 
buffer ( $\mathrm{pH}$ 6.5) containing $2 \mathrm{~mm}$ dithiothreitol and 1\% (w/v) polyvinylpyrolidone. The homogenate was filtered through four layers of cheesecloth and centrifuged at $27,000 \times g$ for $10 \mathrm{~min}$ at $4 \mathrm{C}$. The supernatant was decanted and set on ice as enzyme extract. PDC was assayed through coupling with the ADH reaction by mixing $0.45 \mathrm{ml}$ of $100 \mathrm{~mm}$ MES buffer ( $\mathrm{pH} 6.5), 0.1 \mathrm{ml}$ of $5 \mathrm{~mm}$ thiamine pyrophosphate, $0.1 \mathrm{ml}$ of $50 \mathrm{~mm} \mathrm{MgCl}_{2}, 0.05 \mathrm{ml}$ of 1.6 mM NADH, $0.1 \mathrm{ml}$ of commercial ADH solution (containing 13.5 enzyme units), $0.1 \mathrm{ml}$ of enzyme extract, and $0.1 \mathrm{ml}$ of $50 \mathrm{~mm}$ pyruvate. ADH activity was measured by mixing $0.8 \mathrm{ml}$ of $100 \mathrm{~mm}$ MES buffer (pH 6.5), $0.05 \mathrm{ml}$ of $1.6 \mathrm{~mm}$ NADH, $0.1 \mathrm{ml}$ of enzyme extract, and $0.05 \mathrm{ml}$ of $80 \mathrm{~mm}$ acetaldehyde. For both PDC and $\mathrm{ADH}, \mathrm{NADH}$ oxidation was measured by recording the decrease in absorbance at $340 \mathrm{~nm}$ over time using a spectrophotometer.

The AAT extraction and assay method was modified from that of Fellman et al. (1993b). To extract AAT, $6 \mathrm{~g}$ of tissue was sliced from three fruit and frozen in liquid $\mathrm{N}_{2}$. The sample was ground in $12 \mathrm{ml}$ of $100 \mathrm{~mm}$ potassium phosphate buffer $(\mathrm{pH} \mathrm{7.5)}$ and $2 \mathrm{~g}$ polyvinylpolypyrolidone using a precooled mortar and pestle. After thawing, the sample was filtered through four layers of cheesecloth and centrifuged at $27,000 \times g$ for $15 \mathrm{~min}$ at $4 \mathrm{C}$. The supernatant was decanted and set on ice as enzyme extract. AAT activity was assayed by mixing $0.75 \mathrm{ml}$ of $100 \mathrm{~mm}$ potassium

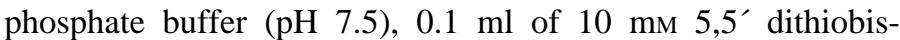
nitrobenzoic acid (DTNB), $0.01 \mathrm{ml}$ of $1 \mathrm{M} \mathrm{MgCl}_{2}, 0.1 \mathrm{ml}$ of enzyme extract, $0.02 \mathrm{ml}$ of $20 \mathrm{~mm}$ isoamyl alcohol, and $0.02 \mathrm{ml}$ of $50 \mathrm{~mm}$ acetyl CoA. The increase in absorbance at $412 \mathrm{~nm}$ over time was measured by a spectrophotometer to follow the production of a yellow thiophenol product (2-nitro-5-thiobenzoic acid) formed by the reaction of DTNB with free CoA released from the AAT esterification reaction.

Enzyme activities were expressed as millimoles of substrate used or product formed per minute per gram fresh weight. For in vitro studies of enzyme kinetics, several assay $\mathrm{pH}$ values were used to study the changes in PDC, ADH, and AAT activities. For PDC and $\mathrm{ADH}, 100 \mathrm{~mm}$ MES buffer was used for $\mathrm{pH} 4.5$ to $7.5 ; 100 \mathrm{~mm}$ tris buffer was used for $\mathrm{pH} 7.5$ to 8.0. For AAT, 100 mM potassium phosphate buffer was used for $\mathrm{pH} 6.0$ to $7.5 ; 100 \mathrm{~mm}$ tris buffer was used for $\mathrm{pH} 7.5$ to 8.5 . The activities at $\mathrm{pH} 7.5$ were the averages of the two buffers used.

\section{Results and Discussion}

Exposing 'Chandler' strawberries to $0.25 \% \mathrm{O}_{2}, 21 \% \mathrm{O}_{2}+50 \%$ $\mathrm{CO}_{2}$, or $0.25 \% \mathrm{O}_{2}+50 \% \mathrm{CO}_{2}$ at $5 \mathrm{C}$ for 1 to 7 days greatly increased concentrations of acetaldehyde, ethanol, ethyl acetate, and ethyl
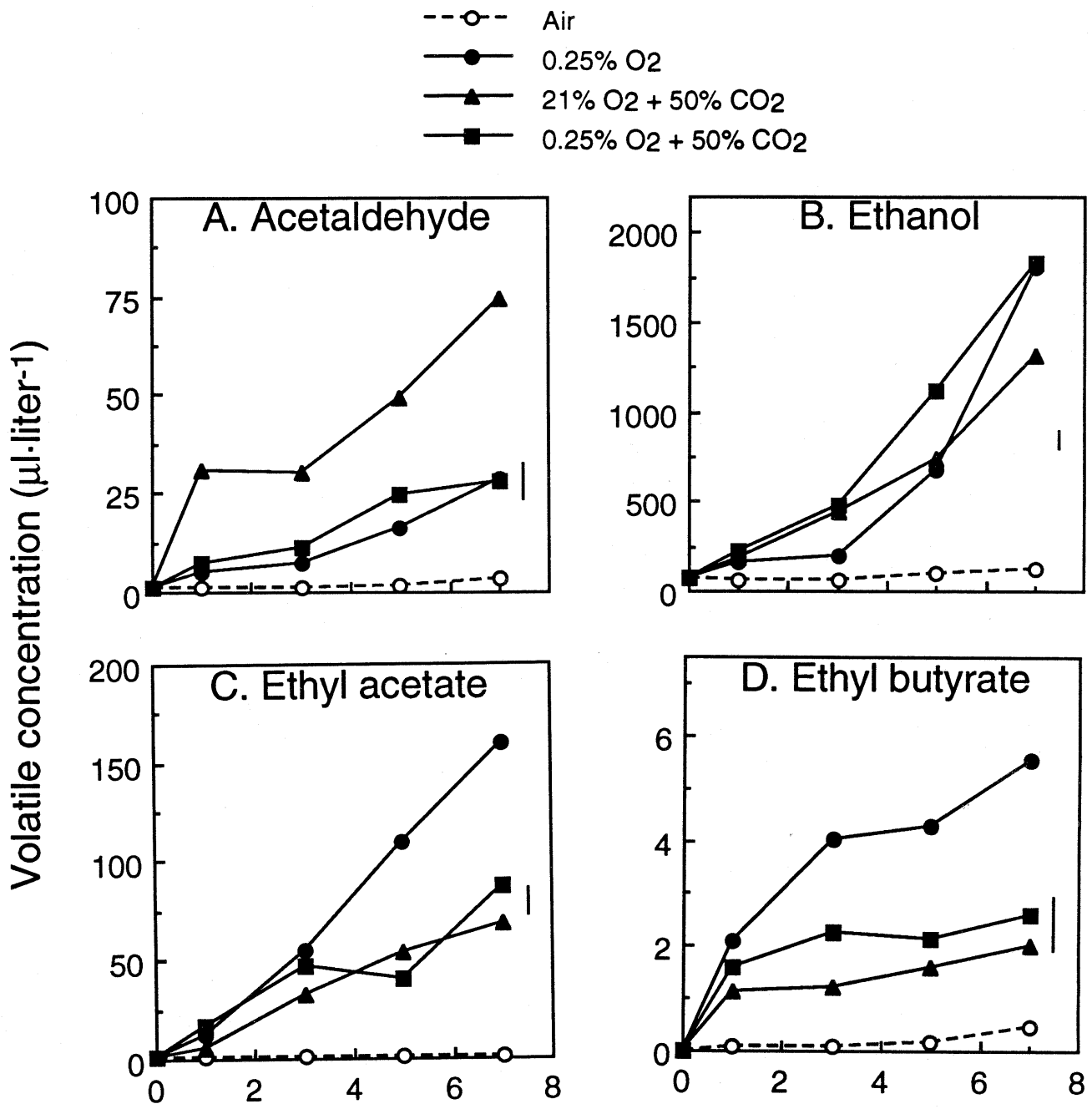

\section{Day}

Fig. 1. Changes in concentrations of acetaldehyde, ethanol, ethyl acetate, and ethyl butyrate of 'Chandler' strawberries kept in air, $0.25 \% \mathrm{O}_{2}, 21 \% \mathrm{O}_{2}+50 \% \mathrm{CO}_{2}$, or $0.25 \%$ $\mathrm{O}_{2}+50 \% \mathrm{CO}_{2}$ at $5 \mathrm{C}$ for $1,3,5$, or 7 days. The vertical bars represent LSD at $P=0.05$. 
butyrate over those of air-control fruit (Fig. 1). While $21 \% \mathrm{O}_{2}+$ $50 \% \mathrm{CO}_{2}$ caused the highest acetaldehyde concentration (Fig. 1A), $0.25 \% \mathrm{O}_{2}$ caused the greatest accumulations of ethyl acetate (Fig. 1C) and ethyl butyrate (Fig. 1D). The three CA treatments generally resulted in lower concentrations of other acetate esters (isopro-

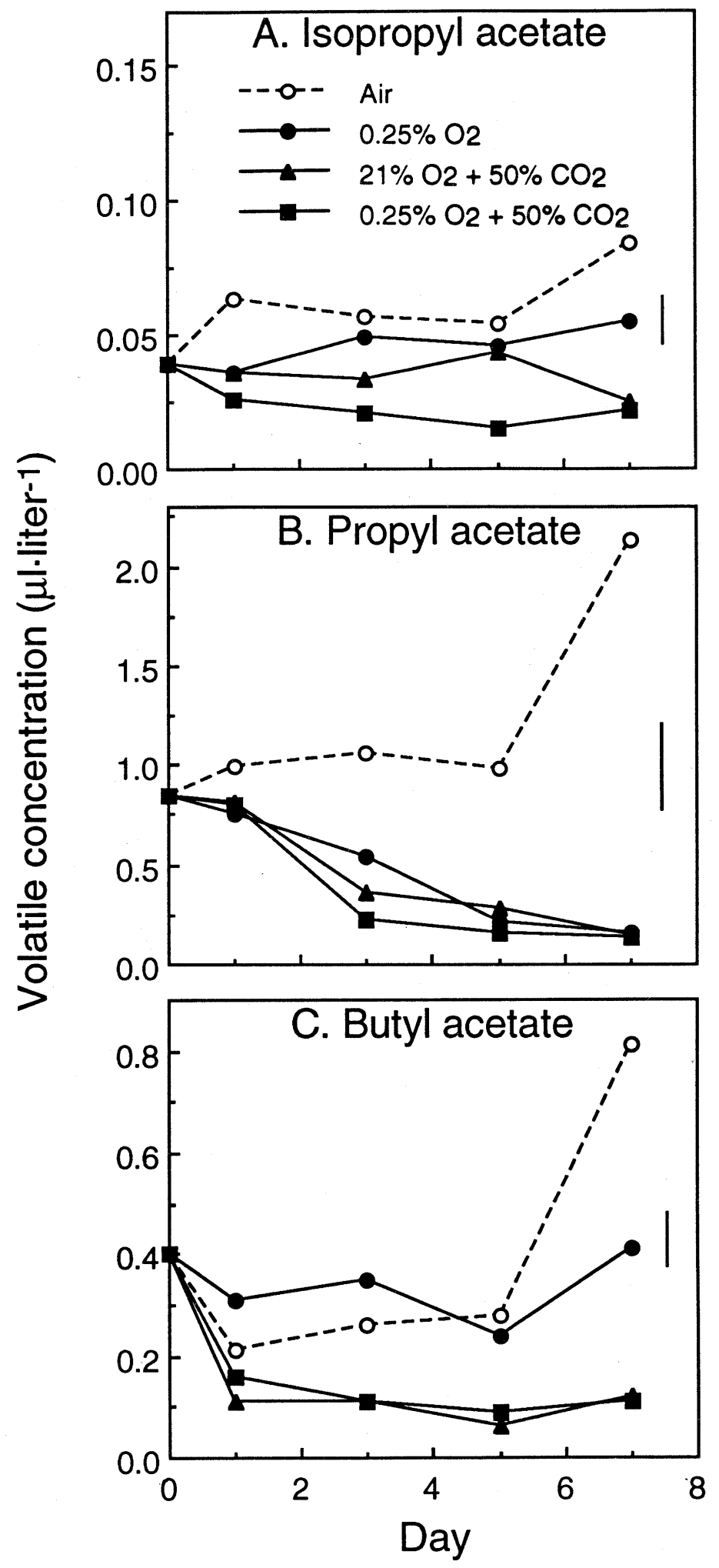

Fig. 2. Changes in concentrations of isopropyl acetate, propyl acetate, and butyl acetate of 'Chandler' strawberries kept in air, $0.25 \% \mathrm{O}_{2}, 21 \% \mathrm{O}_{2}+50 \% \mathrm{CO}_{2}$, or $0.25 \% \mathrm{O}_{2}+50 \% \mathrm{CO}_{2}$ at $5 \mathrm{C}$ for $1,3,5$, or 7 days. The vertical bars represent LSD at $P=0.05$. pyl acetate, propyl acetate, and butyl acetate) compared to those of air-control fruit (Fig. 2).

Changes in concentrations of volatiles may influence flavor. At relatively low concentrations, acetaldehyde, ethanol, ethyl acetate, and ethyl butyrate may enhance fruit flavor (Pesis et al., 1989;

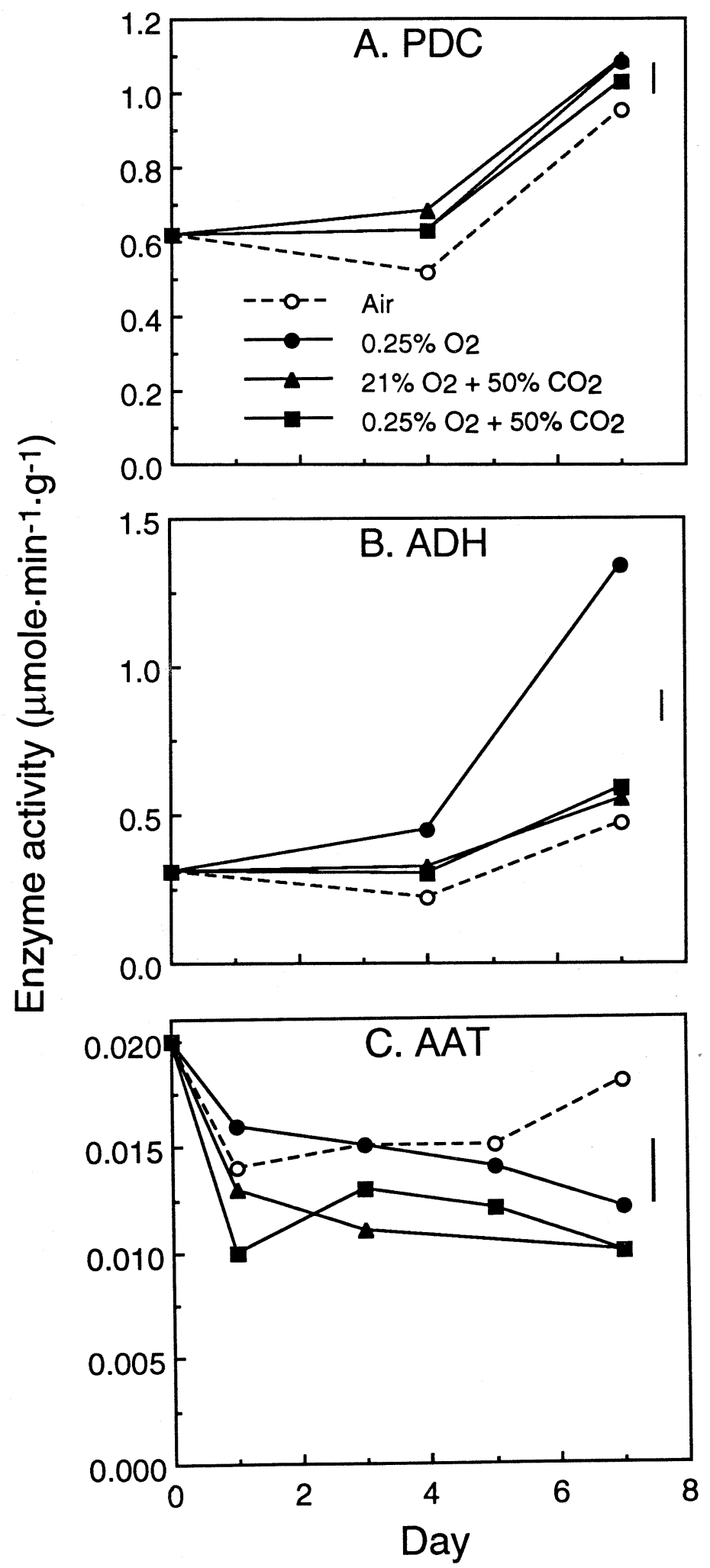

Fig. 3. Changes in activities of pyruvate decarboxylase (PDC), alcohol dehydrogenase $(\mathrm{ADH})$, and alcohol acetyltransferase (AAT) of 'Chandler' strawberries kept in air, $0.25 \% \mathrm{O}_{2}, 21 \% \mathrm{O}_{2}+50 \% \mathrm{CO}_{2}$, or $0.25 \% \mathrm{O}_{2}+50 \% \mathrm{CO}_{2}$ at $5 \mathrm{C}$ for up to 7 days. The vertical bars represent LSD at $P=0.05$. 
Shaw et al., 1990). However, too-high concentrations of these fermentation volatiles may cause off-flavor (Ke et al., 1991; Pesis et al., 1989). Decreased concentrations of other acetate esters may also result in lack of characteristic flavor.

Storing strawberries in $0.25 \% \mathrm{O}_{2}, 21 \% \mathrm{O}_{2}+50 \% \mathrm{CO}_{2}$, or $0.25 \%$ $\mathrm{O}_{2}+50 \% \mathrm{CO}_{2}$ increased PDC and $\mathrm{ADH}$ activities but slightly decreased AAT activity compared to those of air-control fruit (Fig. 3). The $0.25 \% \mathrm{O}_{2}$ treatment enhanced $\mathrm{ADH}$ activity the most (Fig. 3B) and reduced AAT activity the least (Fig. 3C). The in vitro studies

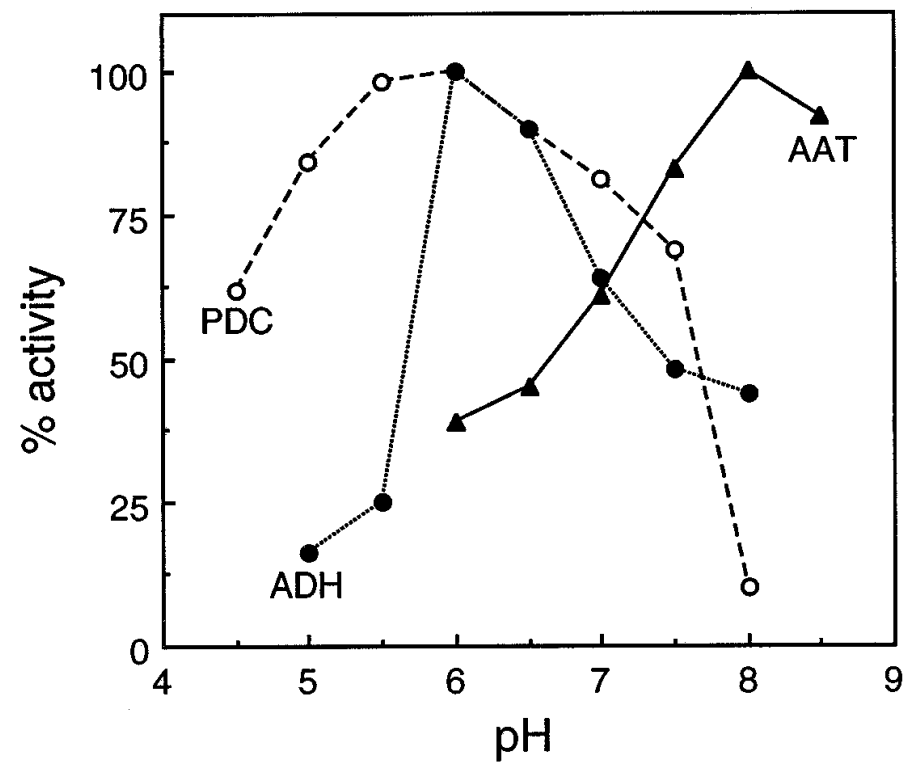

Fig. 4. Effects of $\mathrm{pH}$ on relative activities of pyruvate decarboxylase (PDC), alcohol dehydrogenase (ADH), and alcohol acetyltransferase (AAT) extracted from fresh 'Chandler' strawberries. indicated that PDC and ADH had an optimal $\mathrm{pH}$ of 6.0, while AAT had an optimal pH of 8.0 (Fig. 4). It has been found that exposing fruit and vegetables to low $\mathrm{O}_{2}$ and/or high $\mathrm{CO}_{2}$ reduced cytoplasmic pH (Chavez, 1991; Nanos and Kader, 1993; Siriphanich and Kader, 1986); high $\mathrm{CO}_{2}$ affected $\mathrm{pH}$ more than low $\mathrm{O}_{2}$ (Hess et al., 1993). In most plant tissues, cytoplasmic $\mathrm{pH}$ is $\approx 7$ and CA treatments reduce the $\mathrm{pH}$ by 0.2 to 0.8 units. If strawberries are affected similarly, then a reduced $\mathrm{pH}$ by $\mathrm{CA}$ treatments may have activated PDC and ADH activities but inhibited AAT activity (Fig. 4).

The induction and/or activation of PDC and ADH (Fig. 3) by CA treatments was consistent with the increased acetaldehyde and ethanol concentrations (Fig. 1). Ethanol and acetyl CoA are the substrates for ethyl acetate biosynthesis. Since AAT activity was slightly reduced by CA treatments (Fig. 3C), it seemed that the dramatic increase in ethanol concentration (Fig. 1B) was the major driving force for ethyl acetate accumulation (Fig. 1C). The slight reduction in AAT activity may have partly counteracted the effect of ethanol on ethyl acetate accumulation. It was the combination of AAT activity and ethanol concentration that determined ethyl acetate concentration.

AAT activity and ethanol concentration play a major role in determining the concentrations of acetate esters. AAT catalyzes the esterification reactions to produce acetate esters. The reduced AAT activity by CA treatments was a major reason for the decreased concentrations of isopropyl acetate, propyl acetate, and butyl acetate.

Ethyl acetate and the other three acetate esters share acetyl CoA as one of their substrates. The dramatic increase in ethanol used a lot of acetyl $\mathrm{CoA}$ to produce ethyl acetate, which may have competed with the other alcohols for acetyl CoA and limited the availability of this substrate for the biosynthesis of other acetate esters. The increased ethanol concentration also caused the accumulation of ethyl butyrate (Fig. 1D), since ethanol is one of its

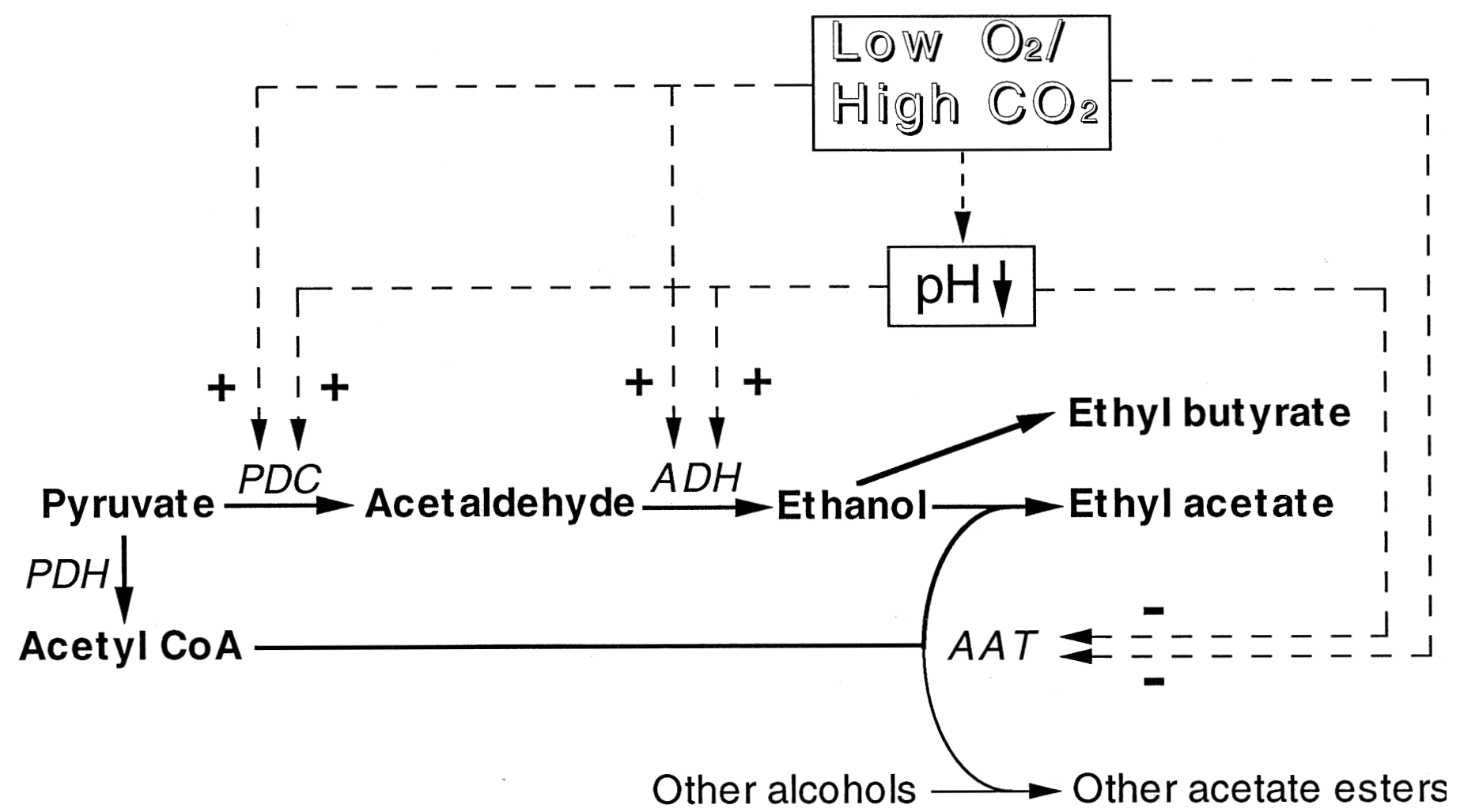

Fig. 5. Proposed mode of $\mathrm{O}_{2}$ and $\mathrm{CO}_{2}$ action on ester biosynthesis of strawberries. AAT $=$ alcohol acetyltransferase; $\mathrm{ADH}=$ alcohol dehydrogenase; $\mathrm{PDC}=$ pyruvate decarboxylase; $\mathrm{PDH}=$ pyruvate dehydrogenase; + is induction and/or activation; - is reduction and/or inhibition. 
substrates. It has been reported that CA treatments in apples and oranges also caused accumulations of ethyl esters but decreased concentrations of acetate esters (such as propyl acetate and butyl acetate) and other esters requiring the same carboxylic acid group for synthesis (Hansen et al., 1992; Mattheis et al., 1991; Shaw et al., 1990). This result indicates that ethanol competes with other alcohols for carboxyl groups in esterification reactions. This idea was further supported by the observation that applying ethanol or acetaldehyde vapor postharvest to apples and strawberries caused accumulations of ethyl esters but reduced concentrations of other esters (Berger and Drawert, 1984; Pesis et al., 1989).

\section{Conclusions}

Using the results from this study and the cited references, a proposed mode of CA action on ester biosynthesis in strawberries is presented in Fig. 5. In this model, low $\mathrm{O}_{2}$ and/or high $\mathrm{CO}_{2}$ concentrations decreased cytoplasmic $\mathrm{pH}$. The CA treatment (directly) and the decrease in $\mathrm{pH}$ (indirectly) enhance PDC and $\mathrm{ADH}$ activities but reduce AAT activity. As a result, acetaldehyde and ethanol accumulate. The great increase in ethanol concentration causes the accumulation of ethyl acetate and ethyl butyrate. The reduced AAT activity and limited availability of acetyl CoA due to competition by ethanol decrease concentrations of other acetate esters (such as isopropyl acetate, propyl acetate, and butyl acetate). Also, CA treatments induce ethanol accumulation, which causes the production of ethyl esters and the reduction of other esters. These changes in volatile profiles may influence fruit flavor.

\section{Literature Cited}

Aharoni, Y., P. Hartsell, J.K. Stewart, and D.K. Young. 1979. Control of western flower thrips on harvested strawberries with acetaldehyde in air, 50\% carbon dioxide or 1\% oxygen. J. Econ. Entomol. 72:819-822.

Berger, R.G. and F. Drawert. 1984. Changes in the composition of volatiles by post-harvest application of alcohols to Red Delicious apples. J. Sci. Food Agr. 35:1318-1325.

Chavez, S.H. 1991. Effects of $\mathrm{CO}_{2}$ levels on ethylene biosynthesis and action in pear fruit (Pyrus communis L.). PhD diss. Univ. of California, Davis.

Couey, H.M., M.N. Follstad, and M. Uota. 1966. Low oxygen atmospheres for control of postharvest decay of fresh strawberries. Phytopathology 56:1339-1341.

Couey, H.M. and J.M. Wells. 1970. Low oxygen or high carbon dioxide atmospheres to control postharvest decay of fresh strawberries. Phytopathology 60:47-49.

El-Kazzaz, M.K., N.F. Sommer, and R.J. Fortlage. 1983. Effect of different atmospheres on postharvest decay and quality of fresh strawberries. Phytopathology 73:282-285.

Fellman, J.K., J.P. Mattheis, M.E. Patterson, D.S. Mattinson, and B.C. Bostick. 1993b. Study of ester biosynthesis in relation to harvest maturity and controlled atmosphere storage of apples (Malus domestica
Borkh.). Proc. 6th Intl. Controlled Atmosphere Res. Conf., NRAES-71, Cornell Univ., Ithaca, N.Y. p. 500-507.

Fellman, J.K., D.S. Mattinson, B.C. Bostick, J.P. Mattheis, and M.E. Patterson. 1993a. Ester biosynthesis in 'Rome' apples subjected to lowoxygen atmospheres. Postharvest Biol. Technol. 3:201-214.

Hansen, K., L. Poll, and C.E. Olsen. 1992. The influence of oxygen concentration in storage atmospheres on the post-storage volatile ester production of 'Jonagold' apples. Lebensm Wiss. u-Technol. 25:457461.

Harada, M., Y. Ueda, and T. Iwata. 1985. Purification and some properties of alcohol acetyltransferase from banana fruit. Plant Cell Physiol. 26:1067-1074.

Harris, C.M., and J.M. Harvey. 1973. Quality and decay of California strawberries stored in $\mathrm{CO}_{2}$-enriched atmospheres. Plant Dis. Rpt. 57:4446.

Hess, B., D. Ke, and A.A. Kader. 1993. Changes in intracellular pH, ATP, and glycolytic enzymes in 'Hass' avocado in response to low $\mathrm{O}_{2}$ and high $\mathrm{CO}_{2}$ stresses. Proc. 6th Intl. Controlled Atmosphere Res. Conf., NRAES71, Cornell Univ., Ithaca, N.Y. p. 1-9.

Ke, D., L. Goldstein, M. O’Mahony, and A.A. Kader. 1991. Effects of short-term exposure to low $\mathrm{O}_{2}$ and high $\mathrm{CO}_{2}$ atmospheres on quality attributes of strawberries. J. Food Sci. 56:50-54.

Ke, D., M. Mateos, and A.A. Kader. 1993. Regulation of fermentative metabolism in fruits and vegetables by controlled atmospheres. Proc. 6th Intl. Controlled Atmosphere Res. Conf., Cornell Univ., Ithaca, N.Y. p. $63-77$.

Li, C. and A.A. Kader. 1989. The residual effects of controlled atmospheres on postharvest physiology and quality attributes of strawberries. J. Amer. Soc. Hort. Sci. 114:629-634.

Mattheis, J.P., D.A. Buchanan, and J.K. Fellman. 1991. Change in apple fruit volatiles after storage in atmosphere inducing anaerobic metabolism. J. Agr. Food Chem. 39:1602-1605.

Nanos, G.D. and A.A. Kader. 1993. Low $\mathrm{O}_{2}$-induced changes in $\mathrm{pH}$ and energy charge in pear fruit tissue. Postharvest Biol. Technol. 3:285-291.

Pesis, E., R. Marinansky, and I. Avissar. 1989. Effect of prestorage treatments with acetaldehyde vapors or anaerobic conditions on volatiles accumulation during storage of various fruits. Acta Hort. 258:661-667.

Prasad, M. and G.L. Stadelbacher. 1974. Effects of acetaldehyde vapor on postharvest decay and market quality of fresh strawberries. Phytopathology 64:948-951

Shaw, P.E., R.D. Carter, M.G. Moshonas, and G. Sadler. 1990. Controlled atmosphere storage of oranges to enhance aqueous essence and essence oil. J. Food Sci. 55:1617-1619.

Siriphanich, J. and A.A. Kader. 1986. Changes in cytoplasmic and vacuolar $\mathrm{pH}$ in harvested lettuce tissue as influenced by $\mathrm{CO}_{2}$. J. Amer. Soc. Hort. Sci. 111:73-77.

Smith, W.H. 1957. The application of precooling and carbon dioxide treatment to the marketing of strawberries and raspberries. Sci. Hort. 12:147-153.

Ueda, Y. and J.H. Bai. 1993. Effect of short term exposure of elevated $\mathrm{CO}_{2}$ on flesh firmness and ester production of strawberry. J. Jpn. Soc. Hort. Sci. 62:457-464.

Woodward, J.R. and A.J. Topping. 1972. The influence of controlled atmospheres on the respiration rates and storage behavior of strawberry fruits. J. Hort. Sci. 47:547-553. 